\title{
Hanefî Usûlünde Hadis Tenkidi
}

\section{Mutlu Gül}

İstanbul: Marmara Üniversitesi İlahiyat Fakültesi Vakfı Yayınları, 2018, 328 sayfa

ISBN 9789755484556

Müelliflerinin çoğunlukla Şâfî̀ mezhebine mensup âlimler olması sebebiyle hadis usulü eserlerinde Şâfî̀ yaklaşımının hâkim olduğuna dair görüşlerin, Hanefî mezhebinin hadis tenkit anlayışına yönelik akademik çalışmaları arttırdığ 1 görülmektedir. Mutlu Gül tarafından yayımlanan Hanefî Usûlünde Hadis Tenkidi adlı kitap bu kapsamda yapılmış yeni çalışmalardan biridir. Söz konusu çalışma, Uludağ Üniversitesi Sosyal Bilimler Enstitüsü’nde aynı başlıklı 2014 yılında tamamlanan doktora tezinin gözden geçirilip düzeltmeler yapılarak kitaplaştırılmış halidir. Çalışma, rivayetleri sened ve metin açısından ele alması yönüyle hadis ilminin, Hanefî mezhebinin hadis anlayışını işlemesi cihetiyle de usûl-i fikhın kapsamına girmesi sebebiyle disiplinler arası bir mahiyet arzetmektedir.

Eser giriş ve üç bölümden oluşmaktadır. Girişte konunun bağlamı ve kapsamı ile takip edilen yöntem ve kullanılan kaynaklar hakkında bilgi verilirken, birinci bölüm Hanefîler'in isnad tenkidi, râvi ve sened tenkidi başliklarını içermektedir. Râvi tenkidi başlı̆̆ı altında râvide aranan şartlar ile haberi delil olarak kullanılan râviler; sened tenkidi başlığ 1 altında ise rivayetlerin taksimi, rivayette inkıta ile haber alma ve aktarma yolları işlenmiştir. Muhteva tenkidinin ele alındığı ikinci bölümde fukahanın muhteva tenkidi olarak arz konusu, arz usulü ile kriterleri başlıkları altında ele alınmıştır. Arz kriterleri Kur'an'a, sünnete, Selef'in icmâına ve akla arz ile umûmü'l-belvâda haberin âhâd olarak nakli, sahabenin rivayetle amel etmemesi ve râvinin rivayetine muhalefeti başlıkları altında ve de ilk dönem Hanefî usul eserlerinde zikredilen örnek haberler rivayet usulü açısından tahlil edilerek incelenmiştir. Hanefî fakihleri ile muhaddislerin hadis anlayışının mukayesesinin yapıldı̆̆ı üçüncü bölümde, hadisçinin ve fakihin rivayet algısına dair değerlendirmelerin ardından isnad ve metin yönünden mukayeselere yer verilmiştir. Kitap, çalışmanın genel bir özeti mahiyetindeki sonuç kısmıyla tamamlanmaktadır.

Yazar bu araştırmadaki amacını "hadis tenkidi faaliyetinin sadece muhaddislere veya sened kritiğinin muhaddislere, muhteva kritiğinin ise daha ziyade fukahâya ait olduğu şeklindeki bir ön kabulden uzak durarak, Hanefî fakihlerinin hem sened hem de metin açısından hadis tenkidine yaklaşımının 
değerlendirilmesi ve hadis ilmine yapacağı katkıların tespiti” şeklinde açıklamıştır (s. 13). Kapsamını da Hz. Peygamber'den aktarılan ve daha ziyade fikhî hükümler içeren rivayetler konusunda, Hanefî mezhebi usulcülerinin hadislerin sübutu ve anlaşılması noktasında belirttikleri tenkit kriterleri, erken dönem usulcülerinden Cessâs (ö. 430/1039), Debûsî (ö. 430/1039), Pezdevî (ö. 482/1086) ve Serahsînin (ö. 483/1090) usule dair eserleri çerçevesinde ele almak; ayrıca teorik olarak belirtilen bu kriterlerin pratikteki karşılığını göstermesi açısından, bu eserlerde yer alan rivayetler üzerinden fukahanın hadise yaklaşımını tahlil etmek olarak ortaya koymuştur (s. 20). Kulland1ğ yöntemle ilgili olarak da araştırmada yer alan başlıkları sözü geçen usul eserlerindeki bilgilerden hareketle tespit ettiğini, ancak her bir başlık altında konu işlenirken sadece Hanefîler'in görüşleriyle yetinmeyerek varsa o konuda hadis usulündeki genel yaklaşıma da mutlaka değinmeye çalışacağını ifade etmiştir. Sened ve metin tenkidi için belirlenen esasları izah ettikten sonra Hanefî usulcülerinin tenkit uygulamasını örnekler üzerinden göstereceğini ve mukayese imkânı vermesi için o konuda muhaddislerin kanaatlerine de işaret edeceğini belirtmiştir (s. 20).

Hanefî usulündeki hadis tenkit kriterlerinin erken dönem eserlerinden Cessâs, Debûsî, Pezdevî ve Serahsînnin usule dair eserleri çerçevesinde tespit edileceğinin belirtilmesi önem arzetmektedir. Yazarın inceleyebildiği eserler -ve tabii ki isimlerini anmamasından hareketle incelemediği anlaşılan çalışmalar- böylece belirtilmiş olsa da bu dört usul eserinin hangi gerekçelerle seçilip diğerlerinin dışarıda bırakıldığının açıklanmaması bir eksiklik olarak gözükmektedir. Adı geçen eserlerin Hanefî hadis tenkit usulünü temsil kabiliyetleri üzerinden bir gerekçelendirme yapılarak okuyucuya da bunu sorgulayabilme imkânı tanınması daha uygun olurdu.

"Yöntem" başlı̆̆ı altında yer alan "Araştırma, rivayetlerin değerlendirilmesinde daha ziyade metne yönelik vurguları ön plana çıkan Hanefî usûlcülerinin, metin ve muhteva tenkidinin yanında sened ve râvilerle alakalı kriterlere de sahip oldukları gerçeğinden hareket etmektedir" şeklindeki ifade, kastını aşmadıysa, araştırmada Hanefî usulcülerinin sened ve râvilerle ilgili kriterlere sahip olduğuna dair belli bir ön kabulle yola çıkıldığı izlenimi vermektedir. Ayrıca yazarın bu yaklaşımı kendisiyle de çelişen bir durum arzetmektedir. Zira o, yukarıda da geçtiği üzere hadis tenkidi faaliyetinin sadece muhaddislere veya sened kritiğinin muhaddislere, muhteva kritiğinin ise daha ziyade fukahaya ait olduğu şeklindeki bir ön kabulden uzak duracağından söz ederken burada başka bir ön kabule takılmış görünmektedir.

Zengin bir kaynakçaya sahip olsa da alanda yakın zamanda çıkan Mehmet Özşenel'in Arz Yöntemi Özelinde Hanefî Hadis Anlayışııın Teşekkülü adlı 
eserinin bibliyografyada yer almayışı dikkati çekmektedir. Ayrıca Leknevînin Zaferü'l-emânî isimli eserinin çok sayıda hata içeren Takıyyüddin en-Nedvî neşrinde olduğu gibi bazı eserlerin problemli tahkiklerinin kullanıldığ 1 da görülmektedir.

Bölüm başlıkları kapsayıcı ve dengeli olmakla beraber, bazı alt başlıklar arasında kimi uyumsuzluklar göze çarpmaktadır. Bir örnek vermek gerekirse, birinci bölümün "B" kısmında "Haberi Delil Olarak Kullanılan Râviler" üst başlı̆̆ 1 altındaki "1. Ma'rûf Râvi”nin alt başlıkları hem kendi aralarında hem de üst başlıkla uyumlu değildir. Zira "1. Ma'rûf Râvi”den "a) Fakih Râvi"ye nasıl geçildiği bir tarafa "c) Habere Tercih Edilen Kıyas"n ma'rûf râvi ile hiyerarşik ilişkisi açık değildir. Genel olarak kitabın bölümlerine bakıldığında ise bunların kitabın adını karşıladığı ve kapsadığı, dolayısıyla da isimle müsemmanın örtüştügü görülmektedir.

Bölümleri ayrı ayrı değerlendirmek gerekirse isnad tenkidini ele alan birinci bölümün tezin esas bölümünü teşkil ettiğini söylemek mümkündür. Zira bu bölüm Hanefîler'in yeterince isnad tenkidiyle meşgul olmadıkları yönündeki genel kanaatin doğru olmadığını ispat amacı da güden eserin en önemli bölümüdür. Burada Hanefîler'in isnad tenkit kriterleri başarılı bir şekilde tespit ve tasnif yanında genişçe izah edilmiştir. İkinci bölümün başlığını "metin tenkidi" değil de "muhteva tenkidi” șeklinde koymuş olmasını yazar, hadisin Kur'an, sünnet ve akıl gibi asıllara arz noktasında "metin tenkidi” kavramının kastedileni karşılamadığı, bu tabirin (textual criticism) Batı menşeli olduğu ve kaynak kritiği, nüsha karşılaştırması, edebî eleştiri gibi daha şümullü bir alana hitap etmesiyle gerekçelendirmiştir (s. 143). Günümüz akademisinde çokça kullanılan fakat farklı şeylerin kastedilmesi sebebiyle açı ve net olmayan bu tabir yerine, yazarın muhteva tenkidi tabirini kullanması isabetli olmuştur. Tez formatında olmadığı halde sonradan eklenen üçüncü bölüme gelince bunun, tezin ikinci bölümünün başında yer alan "I. Hadisçinin ve Fakihin Metin Algısı" başlıklı kısmın alınıp başka başlıklar da eklenerek genişletilmesiyle oluşturulduğu anlaşılmaktadır. Bölümün girişinde yazarın, esas olarak Hanefî fukahasının sened ve metinlere dair belirledikleri kriterlerin hadis ilmine yapabileceği katkılar üzerinde duracağını, fakat bunun için öncelikle hadisçilerin ve fukahanın rivayetlere bakışlarını mukayeseli olarak ele almayı uygun bulduğuna dair ifadeleri (s. 267) ile bölüm başlığı uyuşmamaktadır. Zira "Hanefî Fakihleriyle Muhaddislerin Hadis Anlayışının Mukayesesi” şeklinde bölüm başlığı katkıların değil mukayesenin esas olarak ele alınmasını gerektirmektedir. Zaten bölümün içindeki başlıklar da mukayeseyi esas alır bir yaklaşımla düzenlenmiştir. Sonuç kısmı kitabın kısa bir özeti mahiyetindedir. Kitap içerisinde yeterince tartışılan 
meselelerin vardığı nokta ile ulaşılan sonuçlar yanında konuya emek vermiş birinin kurabileceği cümlelere yer vermesi ve alana ilgi duyan araştırmacılara yol gösterici tavsiyeler sunması beklenen bu kısmın söz konusu beklentiyi karşıladığını söylemek güçtür.

Üsluba değinilecek olursa yazarın genel olarak akıcı bir dil kullandığı görülmektedir. $\mathrm{Bu}$, konusu itibariyle teknik yönü ağır basan böyle bir çalışmayı yorulmadan okunabilir kılmıştır. Bununla birlikte kimi kapalı ifadelerin bulunduğu da belirtilmelidir. Mesela "Râvinin Rivayetine Muhalefeti" ile "Aslen Muhalefet" başlıklarından tam olarak neyin kastedildiği açık değildir. Bu ifadeler yerine "râvinin kendi rivayetine muhalefeti" ve "rivayetin kendisine aidiyetini inkâr etmesi” denilebilirdi. Kitapta göze çarpan kimi yazım hatalarının ise genel ortalamanın altında olduğu söylenebilir. Yine İlahiyat çalışmalarında yaygın bir şekilde görülen Arapça orijinal metin nakillerindeki imla problemleri yanında harekelemedeki tutarsızlığa bu çalışmada da rastlanmaktadır.

Çalışmanın biri esas, diğeri tâli olmak üzere iki iddiasının olduğunu söylemek mümkündür. Bunlardan ilki Hanefîler'in hadislerin kabulünde isnad tenkidine de önem verdikleri şeklinde özetlenebilir. Yazar bu iddiasını ispatta başarılı olmuş gözükmektedir. Zira kitabın Hanefî isnad tenkidini ele alan birinci bölümdeki bilgiler, bunu ispat için yeterli ve ikna edicidir. Ancak bu iddia ile bağlantılı olarak yazarın bir taraftan Hanefî usûlcülerin hadislerin "sübutundan ziyade metin ve muhtevasına yoğunlaştığı"na dair yaygın kanaati doğru bulmayarak karşı çıkarken (s. 19) diğer taraftan söz konusu yaygın kanaati onaylarcasına Hanefî fikıh usulünün muhteva merkezli olduğuna dair ifadeleri (s. 269, 270) çelişkili bir durum arzetmektedir.

Kitabın tâli derecedeki iddiası ise "hadis usulü içerisindeki pek çok alt başlı̆̆ın, fikıh ilminin bu birikiminden istifade ederek, içinde bulunulan zamana, mekana ve şartlara göre revize edilebileceği, geliştirilebileceği” (s. 279) şeklindedir. Yazar bu iddiayı bir adım daha ileriye götürerek "her iki (hadis ve fikıh) yöntemin kullandıkları usullerin, günümüz hadis meselelerini tek başına çözmede yeterli bir niteliğe sahip olduğunu söylemenin zor gözüktügüünü, bu sebeple de "hadislerin tespit ve değerlendirilmesi konusunda her iki usulün birbirini tamamlayacak şekilde memzûc/eklektik bir metodun geliştirilmesi gerektiği"ni savunmuştur (s. 295). Kitapta ele alınışı itibariyle tâli olarak nitelendirdiğimiz ama gerçekte oldukça büyük bir iddia taşıyan bu yaklaşım konusunda eserde iki yöntem arasında belli bir mukayese yapılmakla birlikte, söz konusu revize ve/veya mezcin nasıl yapılacağ üzerinde yeterince durulmadığını söylemek yerinde olacaktır. Zira fikıh usulünden sadece, yapılabilecek sınırlı sayıda katkıya işaret edilmekle yetinilmiş, 
bunların gerçekte katkı sunup sunamayacağı tartışılmadığı gibi pratikteki yansıması üzerinde hemen hiç durulmamıştır. Diğer taraftan aslında yazarın ifadesiyle "iç tutarlığa ve nispeten bütüncül bir yaklaşıma sahip olan" (s. 295) bu ayrı iki yöntemin mezcedilmesiyle ortaya nasıl bir yapının çıkacağı ve bu durumda söz konusu iç tutarlılık ve bütünlügün nasıl korunabileceğine dair de çalışmada yeterli bir açıklamaya rastlanmamaktadır. Bunlar, yazarın söz konusu metodun imkân ve sınırlarını göstermeyi hedeflediğini söylediği bu çalışmasının ilgili bölümünde belki de en çok merak edilen ve cevabı beklenen soruları teşkil etmektedir. Esasen, üçüncü bölümde yer verilen temellendirilmeye muhtaç bu büyük iddianın, müstakil bir çalışmayı fazlasıyla hak ettiği söylenebilir.

Çalışmada tenkide medar olduğunu düşündüğümüz bazı hususlara da temas etmek gerekir ki, bunlardan dikkati çeken bazı tespitler şöyledir: Yazarın "tâbiîn dönemi olarak bilinen II. (VIII.) yüzyıl..." (s. 18) ifadesinin tam olarak doğru olduğunu söylemek zordur. Zira tâbiîn dönemi ağırlıklı olarak 65-135 (684-752) yılları arasını kapsamaktadır. Dolayısıyla tâbiîn dönemini II. (VIII.) yüzyıl olarak tavsif etmek, I. (VII.) yüzyılın bu kapsama girmesi gereken yaklaşık son üçte birini dışarıda bırakacağı gibi, II. (VII.) yüzyılın kapsam dışı kalması gereken ikinci yarısını bu döneme dahil etmek anlamına geleceğinden isabetli değildir. Ayrıca fikhî mezheplerin teşekkül sürecinin II. (VIII.) asırda tamamlandığına dair ifade de (s. 18) problemlidir. Çünkü bilindiği gibi dört mezhep imamından İmam Şâfiî 204'te (820), Ahmed b. Hanbel ise 241'de (855) vefat etmiştir. Kaldı ki mezheplerin teşekkülü bir süreç olup sadece mezhebin imamı ile de tamamlanmamaktadır. Bundan başka, adaletin tarifinde geçen "mürûet" kelimesinin "erdem(li olmak)" (s. 40) şeklinde çevrilmiş olması yerinde değildir. Kanaatimizce erdem kelimesi Arapça'da "fazilet" kelimesinin karşıllğı 1 olmaya daha uygudur. Adaletin tarifindeki mürûet kelimesi ise, râvinin kişiliğini zedeleyen iş ve davranışlardan uzak bulunması anlamında kullanıldığ 1 için bunun "şahsiyet/kişilik(li olmak)" şeklinde çevrilmesi daha isabetli olacaktır. Son olarak "fakih/fukaha" ile "usulcü/usulcüler" tabirlerinin kullanımında problem gördügümüzü belirtmeliyiz. Yazarın çalışma boyunca genellikle bu ikisini aynı anlamda ve dolayısıyla birbirinin yerine kullandığı anlaşılmaktadır. Oysa fukaha ile usulcülerin her konuda aynı fikirde olduğunu söylemek zordur. Zira diğer meselelerde olduğu gibi hadise dair konularda ayrı düştükleri pekâlâ olmuştur.

Hatalı gözüken bu noktalardan başka tartışmalı veya teyide muhtaç olduğunu düşündügüumüz bazı hususlar da bulunmaktadır. İmam Şâfiînin er-Risâle’sinin usûl-i fikıh alanına giren konuları sistematik olarak işlediği (s. 21), Arap dünyasında yapılan veya Arapça basılan eserlerde bir sonuç 
kısmının yer almamasının genelde bir usul olarak benimsenmiş olduğu (s. 26), yukarıda sözü geçen Hanefî usûl-i fikıh eserlerinde Kur’an’a arzın gerekçesi olarak zikredilen haberlere, sıhhati ile ilgili herhangi bir değerlendirmede bulunmadan yer vermelerinin onları sahih kabul ettikleri anlamina geldiği (s. 169), Hanefî fakihlerinin amel etmedikleri haberlerin sened aç1sindan bir kusuru varsa bunu mutlaka belirttikleri (s. 173) gibi değerlendirmeler bunlar arasındadır. Kanaatimizce sayılanlar tartışmalı veya en azından teyidi gereken bilgiler olup delillere yahut yeteri derecede örneğe muhtaç hususlardır.

Kitabın alana katkısı meyanında şu hususun ifade edilmesi gerekir ki, yazar fıkıh ilminin terminolojisini iyi ve yerinde kullanması yanında Hanefî usul kaynaklarını başarılı bir şekilde kullanarak değerlendirmiştir. $\mathrm{O}$, bu çalışmasıyla erken dönem Hanefî usul kaynaklarında hadis tenkidine dair dağınık halde yer alan teorik bilgileri tespit ve tasnif etmekle kalmayıp aynı zamanda söz konusu eserlerde geçen rivayetler üzerinden buradaki bilgilerin pratikteki karşılığını göstermeye çalışmıştır. Daha önceki çalışmalarda pek görülmeyen bu uygulama ile yazar bir taraftan Hanefiller'in hadis tenkit anlayışını başarılı bir şekilde tasvir ederken, diğer taraftan onların bu yaklaşımını hadisçiler açısından değerlendirmeye tâbi tutmuştur. Hanefì Usûlünde Hadis Tenkidi, okuyucuların istifade edebileceği, akademik alana katkı sağlar nitelikte bir çalışmadır.

Muhammet Beyler, Dr. Öğr. Üyesi Yalova Üniversitesi İslami İlimler Fakültesi

ORCID 0000-0003-4088-0981

DOI 10.26570/isad. 846715 